\title{
Negotiated Block Trades and Corporate Control
}

\author{
by \\ Michael J. Barclay \\ and \\ Clifford G. Holderness
}

Working Paper Series No.

MERC 89-10

May 1989

Managerial Economics Research Center

William E. Simon Graduate School of Business Administration

University of Rochester

Rochester, NY 14627 
.

. 


\title{
Negotiated Block Trades and Corporate Control
}

\author{
by \\ Michael J. Barclay \\ and \\ Clifford G. Holderness
}

\begin{abstract}
We identify negotiated trades of large-percentage blocks of stock as corporate control transactions involving active investors. One year after a trade, stock prices of the firms whose shares are traded are $5.6 \%$ higher, and $45 \%$ of the chief executives have been replaced. Stock-price increases are larger when a firm performs poorly before the trade, and when management does not resist the blockholder. Even though such blocks often convey the right to choose managers and influence corporate policy, some blockholders eventually acquire the firm, suggesting that corporate control is broader than the right to choose managers.
\end{abstract}




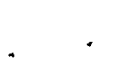

, 
May 11, 1989

\title{
Negotiated Block Trades and Corporate Control
}

\author{
by \\ Michael J. Barclay* \\ and \\ Clifford G. Holderness
}

\section{Introduction}

In this paper we investigate negotiated block trades of at least $5 \%$ of the common stock of New York Stock Exchange (NYSE)- and American Stock Exchange (AMEX)-listed corporations. Our first objective is to study the impact of these transactions on the firms whose shares are traded. We then compare these findings with what is known about control transactions in more diffusely held firms to obtain insights into the broader market for corporate control.

The initial public announcements of the 106 negotiated block trades in our sample are associated with average abnormal stock-price increases of approximately $15 \%$. The increases tend to be larger when the block purchaser eventually tenders for the remaining shares. When the firm continues as an independent public entity, stock prices on average increase with the announcement of the trade, decline gradually over the 40 following days, and remain level thereafter. Even with the decline, however, the cumulative abnormal returns average $5.6 \%$ one year after the trade. Following the trades, turnover among top managers and directors substantially exceeds what is normal for public corporations. For

"University of Rochester, William E. Simon Graduate School of Business Administration. This research has been supported the Managerial Economics Research Center at the Simon School. We would like to thank Richard Cusker, Hesna Genay, and Meeta Kothare for research assistance. The authors are solely responsible for the paper's contents. 
example, in the firms that remain independent public entities, $45 \%$ of the chief executives depart in the year following the trade, with many of their replacements being hired externally. There are also numerous reports in the financial press that the new blockholders or representatives of corporate blockholders play an active role in firm management. In some firms, incumbent management resists efforts by block purchasers to influence corporate decisions.

These findings suggest that negotiated trades of large-percentage blocks of stock should be considered in the broader spectrum of corporate control transactions because they appear to transfer the right to influence, if not to choose outright, the top management team. This expanded view of the market for corporate control is important for both practical and conceptual reasons. On a practical level, negotiated block trades occur relatively often. For example, among NYSE- and AMEX-listed corporations, block trades appear to occur more frequently than either hostile tender offers or proxy contests. There is also eridence that block investing is on the increase both in this country and in Europe. ${ }^{1}$ On a conceptual level, our findings highlight the value of viewing some control transactions not through the traditional paradigm of passive shareholders choosing among competing managerial teams, but in the context of active block investors leading managerial teams and initiating corporate change directly.

Because most of our firms remain independent following a trade, we are able to investigate the sources of value created by block trades, which may be suggestive of the value created in more conventional control transactions. It appears that block trades lead to improved management. Firms that perform poorly before a trade, and which presumably present the greatest opportunities for management improvements, show the largest increases in value following a trade. In contrast, managerial resistance to efforts by blockholders to influence corporate policy typically reduces firm value. We also find that although the acquisition of a large-percentage block typically carries with it the right to choose, discipline, and lead the managerial team, approximately $40 \%$ of our purchasers perceive additional benefits from acquiring the minority's interest (at a substantial

\footnotetext{
${ }^{1}$ For a discussion of the resurgence of block investors, see Jensen (1989).
} 
premium). This suggests that much of the value created by corporate control transactions arises from sources other than the right to select the top management team.

Section 2 describes our sample and documents the major empirical regularities associated with block trades: the abnormal stock-price increases with the initial public announcements, the corporate activities of block purchasers and managerial resistance to those efforts, and the extensive post trade turnover among directors and officers. The section concludes by comparing negotiated block trades, in which active block investors often initiate corporate change, with control transactions in which relatively passive shareholders choose among competing managerial teams. Section 3 investigates the sources of value created by negotiated block trades. First, we determine whether block trades lead to improved management by analyzing the relation between a firm's performance before the trade and the increase in its value associated with the trade. We then investigate the effect of managerial resistance to blockholders on firm value and test the hypothesis that changing managers after a block trade is a major source of value. We next analyze the organizational gains that motivate some of our block purchasers eventually to acquire all outstanding shares. In the conclusion we summarize our major empirical findings and discuss their implications for the broader market for corporate control.

\section{Negotiated block trades: Corporate control with active investors}

\subsection{Sample of block trades}

We obtain a sample of negotiated block trades by examining each entry of the company index of the Wall Street Journal from 1978 through 1982. For inclusion in our sample, there must be a report of a trade of at least $5 \%$ of the common stock of a NYSEor AMEX-listed corporation. We require blocks of at least $5 \%$ because the SEC mandates public filing once that threshold is reached; we limit our analysis to NYSE- and AMEXlisted corporations so that we can use the Center for Research in Security Prices (CRSP) computer listing of daily stock prices. Finally, because we want to focus on negotiated block trades rather than more conventional control transactions, we exclude trades made in response to outstanding merger or tender offers. We do, however, include trades that are announced simultaneously with offers by the block purchaser to acquire the firm's 
remaining outstanding shares. These steps produce a sample of 106 block trades involving 97 corporations.

Details about the trades, the trading parties, and the firms whose shares are traded are obtained by reviewing the Wall Street Journal and the $13 \mathrm{~d}$ filed by the purchaser (if available from Disclosure Inc.). Because we are interested in internal changes following block trades, we collect a variety of additional information from Moody's, Standard and Poor's Register of Corporations, Directors and Officers ("Standard and Poor's Register"), COMPUSTAT, and the Wall Street Joumal Company Index for the year of the trade and the five following years.

To provide a background for our analysis, we report in table 1 the size of the firms whose shares are traded, the percent of the firm's common stock in the block, and whether the trading parties are individuals or corporations. We also report this information after partitioning our sample into trades where the firm continues as an independent public corporation for at least one year after the trade, and trades that are followed within one year by an acquisition of the firm (typically by the block purchaser). ${ }^{2}$ We make this partition throughout the paper, for three reasons. First, we find that several effects of a block trade, including the stock-price reaction to its initial public announcement, vary significantly when there is a follow-up offer to minority shareholders. Second, when a firm continues to be publicly held, more information is available to us and thus more analyses are possible on post-trade changes, including managerial turnover. Third, a block trade leading to the acquisition of the minority's interest is a fundamentally different organizational change from the continuation of the firm as an independent public entity.

(Table 1 goes here)

${ }^{2}$ Seventeen of the trades involve simultaneous tender offers by the block purchaser. In six additional cases such an offer occurs within 30 trading days. Thereafter, tender offers become less frequent and appear to occur randomly. 


\section{Table 1}

Descriptive statistics for 106 negotiated block trades of at least $5 \%$ of the common stock of NYSEor AMEX-listed corporations between 1978 and 1982. The sample of firms remaining independent public entities consists of 65 trades in which the firms whose shares are traded are not acquired within one year of the block trade announcement. The sample of firms subsequently acquired consists of 41 trades in which the firms whose shares are traded are acquired within one year of the block trade announcement. Data from COMPUSTAT, SEC 13d filings, and the Wall Street Journal.

Mean Median Minimum Maximum

All firms

Book value of assets

(Millions of 1982 dollars)

85

2

1680

Percent of common

stock in block

21

5

83

Percent of block buyers

who are individuals

Percent of block sellers

who are Individuals

Firms remaining independent public entities

Book value of assets

(millions of 1982 dollars)

264

86

2

1680

Percent of common

stock in block

21

17

5

63

Percent of block buyers

who are individuals

Percent of block sellers

who are individuals

Firms subsequently acquired

Book value of assets

(millions of 1982 dollars)

221

68

9

1131

Percent of common

stock in block

6

83

Percent of block buyers

who are individuals

Percent of block sellers

who are individuals 


\subsection{Stock-price reaction to initial public announcements of block trades}

To ascertain the abnormal stock-price reaction associated with initial public announcements of block trades, we use the market model to adjust for general movements in stock prices. The intercept and slope coefficients are estimated with a linear regression

of the continuously compounded rate of return of our sample firm on the continuously compounded rate of return on the CRSP equally-weighted index. The estimation period includes day - 720 through day - 240 (approximately two calendar years) with day 0 being the day of the initial Wall Street Journal announcement of the trade. With these estimates, prediction errors are calculated for each day from event day -240 through event day +240 . Cumulative abnormal returns are formed by summing the daily abnormal returns (prediction errors) over various event periods. These cumulative abnormal returns are then averaged across all firms in the sample. The statistical significance of the cumulative abnormal returns are calculated using standardized prediction errors. Each firm's cumulative prediction error is standardized to reflect its estimated standard deviation and then each standardized prediction error is treated as an independent unit normal random variable.

Figure 1 plots the abnormal stock returns from 240 days before through 240 days after the initial public announcements of our block trades. Table 2 summarizes these returns and their significance levels for various parts of the 480 day event period. For the full sample of 106 trades, over the day before the announcement appears in the Wall Street Journal and the announcement day (days -1,0), abnormal stock returns average $5.07 \%$ ( $p$-value of the $t$-statistic is .001). Seventy percent of these returns are positive. Figure 1 also documents an increase in stock prices in the 40 days preceding an announcement. This increase likely reflects leakage of information about a trade, suggesting that the event-day returns are likely to understate the impact of a block trade on firm value. Analysis of stock prices over the 40 days immediately preceding the announcement (days -40 through 0 ) shows abnormal returns of $14.03 \%$ ( $p$-value $=.001$ ). Over the entire 280 day event period, stock prices increase by $16.46 \%$ ( $p$-value $=.001$ ). 
(Figure 1 and table 2 go here)

Figure 1 and table 2 also report abnormal returns when the sample is partitioned into those firms that remain independent public corporations following the trade and those that are acquired within one year. Notwithstanding notable differences between the two subsamples-in particular, returns are considerably larger when a trade is connected with an acquisition-both are associated with stock-price increases. The increases of approximately $30 \%$ for the block trades associated with tender offers, mergers, and goingprivate transactions are comparable to the increases for similar acquisitions in more diffusely held firms.

When the firm remains independent, the average abnormal return increases from day -40 through day 0 , declines from day 1 until day 40 , and remains approximately level thereafter (figure 1). This pattern suggests that the initial increases partially reflect an increased expectation that the minonty's shares will be acquired. As that expectation is not realized, stock prices drift down. Because this subsample excludes firms that are acquired within one year and because stock prices are approximately level from day 40 on, we conclude that the remaining abnormal returns of approximately $5.6 \%$ do not reflect anticipated acquisitions. ${ }^{3}$

\subsection{Block purchasers' corporate activities and management's resistance}

We review Moody's, Standard and Poor's Register, and the Wall Street Journal for a variety of information on events following our block trades. Moody's and Standard and Poor's Register are checked to determine which individual block purchasers become directors and officers. (Because Moody's and Standard and Poor's Register do not list the affiliations of directors and officers, we are unable to determine how often corporate block purchasers place their representatives on the board and in top managerial positions.) The Wall Street Journal is reviewed for reports of block purchasers buying additional

\footnotetext{
${ }^{3}$ Abnormal stock returns calculated by simply subtracting the market return are somewhat larger than the market-model adjusted returns in figure 1 and table 1 . For example, for those firms that continue as independent public entities after a trade, the abnormal returns from day -40 to day 240 are $7 \%$ with the simple market adjustment, versus $5.6 \%$ with the market-model adjustment.
} 


\section{Figure 1}

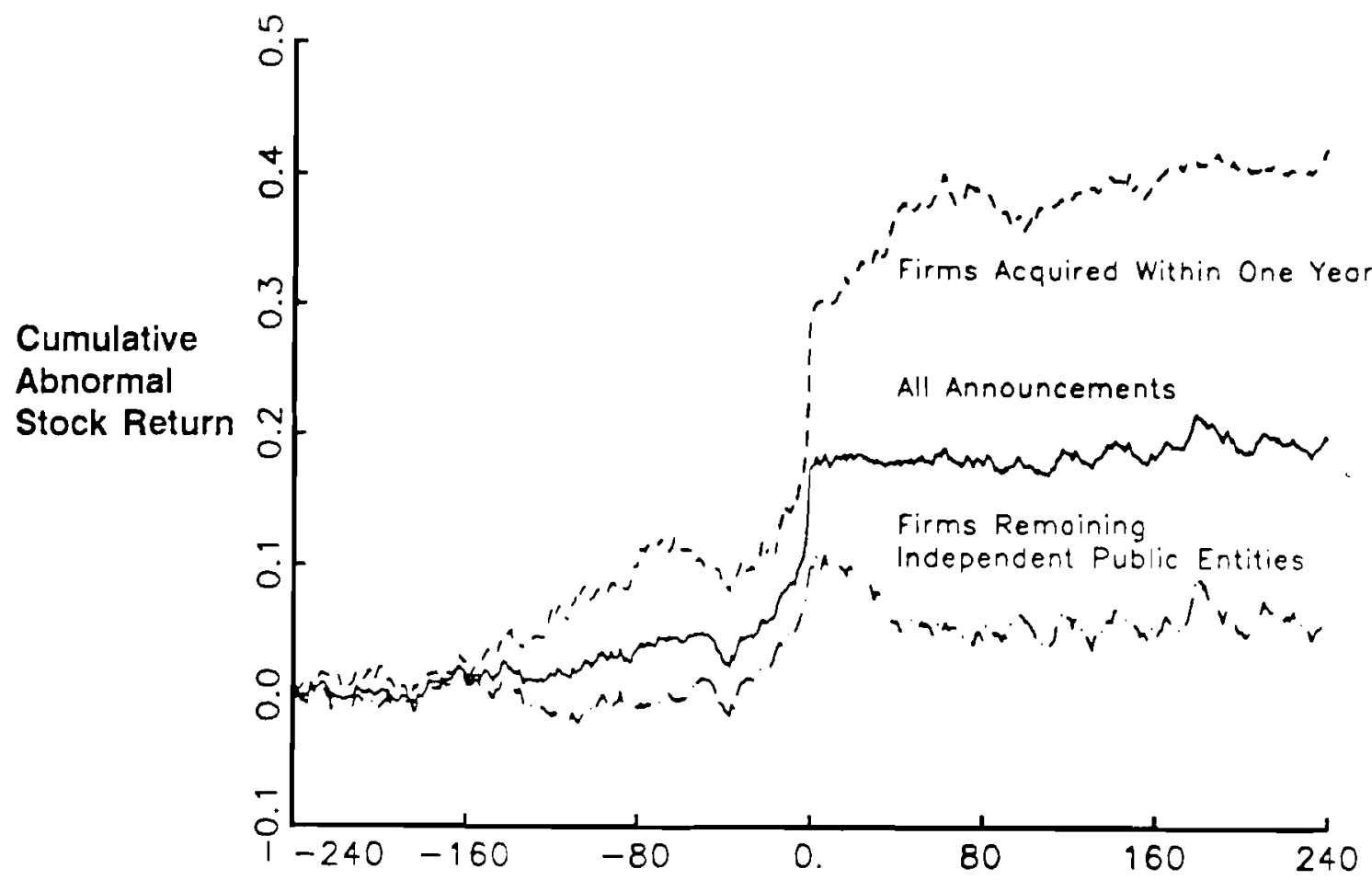

Day in Relation to Block Trade Announcement

Cumulative abnormal returns (market-model prediction errors) associated with 106 initial public announcements of negotiated block trades of at least $5 \%$ of the common stock of NYSE- or AMEXlisted corporations between 1978 and 1982. Day 0 is the day of the initial Wall Street Journal announcement of the block trade. The sample of firms remaining independent public entities consists of 65 trades in which the firms whose shares are traded are not acquired within one year of the block trade announcement. The sample of firms subsequently acquired consists of 41 trades in which the firms whose shares are traded are acquired within one year of the block trade announcement. Data from CRSP and the Wall Street Journal. 


\section{Table 2}

Cumulative abnormal returns (market-model prediction errors) over various event-time intervals associated with 106 initial public announcements of negotiated block trades of at least $5 \%$ of the common stock of NYSE- or AMEX-listed corporations between 1978 and 1982. The sample of firms remaining independent public entities consists of 65 trades in which the firms whose shares are traded are not acquired within one year of the block trade announcement. The sample of firms subsequently acquired consists of 41 trades in which the firms whose shares are traded are acquired within one year of the block trade announcement.

Days In Relation To Initial Block Trade Announcement

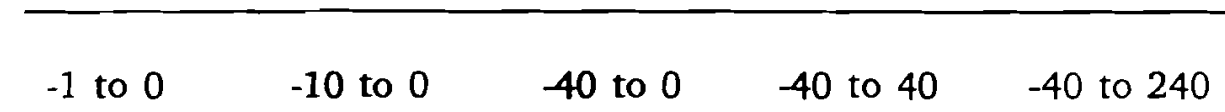

\section{All firms}

Cumulative

abnormal return

5.07

9.21

14.03

14.64

16.46

$p$-value ${ }^{a}$

.001

.001

.001

.001

.001

Firms remaining independent

public entities

Cumulative

abnormal return

2.07

5.54

9.86

5.71

5.62

$p$-value

.020

.001

.001

.034

.322

Firms subsequently

acquired

Cumulative

abnormal return

9.75

14.94

20.54

28.57

33.38

$p$-value

.001

.001

.001

.001

.001

${ }^{a} p$-value for the two-tailed test of the hypothesis that the cumulative abnormal returns are equal to zero. 
stock, as well as for evidence of managerial resistance. This involves resistance to the block seller, manifested through block trades to white knights, and resistance to the block purchaser through litigation, press releases casting doubts on the purchaser's ability or character, and defensive restructurings reported as a response to the new blockholder. Finally, we record all attempted and completed reorganizations, which include mergers, tender offers, and going-private transactions, and the role the block purchasers play in them. This information is summarized in table 3 for the two years following a trade.

(Table 3 goes here)

A pattern of considerable post-trade activity emerges from table 3 , even though the table represents a lower bound on this activity because it incorporates only public reports. We expect a further downward bias because the Wall Street Journal follows large firms more closely than it does small firms and most of our firms are relatively small (table 1). In spite of these factors, however, only 14 firms (13\%) show no evidence of block purchaser involvement in corporate activity or managerial resistance. Fifteen (68\%) of the individual blockholders become directors or officers. ${ }^{4}$ Approximately two-thirds of the block purchases by corporations involve firms in closely related businesses. None of the 106 purchasers break up their blocks, but $30(28 \%)$ add to them. These 30 blockholders add on average $12 \%$ (median $8 \%$ ) to their block purchases (which themselves average $21 \%$, median $18 \%$, with a maximum of $49 \%$ ). Almost half of the block purchasers attempt to take over the firm within two years, and they succeed in $80 \%$ of these attempts. Takeover attempts by others succeed less often.

Managerial resistance to blockholders is reported in 34 firms (32\%). Five of those cases involve block sales to white knights following press reports of managerial resistance to changes proposed by the block seller. Twenty lawsuits are filed by management against a block purchaser. In other instances, management questions the block pur-

\footnotetext{
${ }^{4}$ The individual block purchasers who do not become directors or officers either sell their blocks shortly after acquiring them or make their block investment through a private foreign firm. In the latter case, it is difficult for us to identify any representatives of the block purchaser who may be serving as a director or officer.
} 


\section{Table 3}

Summary of corporate activities of block purchasers and managerial resistance to the blockholders associated with 106 negotiated block trades of at least $5 \%$ of the common stock of NYSE- or AMEX-listed corporations between 1978 and 1982. Information from Wall Street Journal, Moodys, and Standard and Poor's Register of Corporations, Directors and Officers.

$\begin{array}{ccc}\text { Individual } & \text { Corporate } & \\ \text { Block } & \text { Block } & \text { Entire } \\ \text { Purchasers } & \text { Purchasers } & \text { Sample } \\ (\mathrm{N}=22) & (\mathrm{N}=84) & (\mathrm{N}=106)\end{array}$

Individual block purchaser

becomes officer or director

15

NA

NA

Corporate block purchaser

in related business

NA

55

NA

Block purchaser buys

additional stock

5

25

30

Reports of managerial

resistance to blockholder

5

29

34

Reorganization of firm

Number of attempted

reorganizations by

block purchaser

6

45

51

Number successful

5

36

41

Number of attempted

reorganizations by

third party

5

9

14

Number successful

2

5

7

Firms with no indication of block purchaser activity or managerial resistance $^{a}$

4

10

14

${ }^{a}$ An individual block purchaser does not become a director or officer; a corporate block purchaser is not in a related business; the blockholder does not purchase additional stock after acquiring the block; management does not resist the block seller or the block purchaser; and there are no attempts to reorganize the firm. 
chaser's integrity. Five of the blocks are ultimately repurchased by the firm at a premium to the exchange ("greenmail").

Further evidence on the activeness of large-block shareholders in firm management comes from pricing of large-percentage blocks of common stock. Barclay and Holdemess (1989) document that 63 trades of blocks involving at least $5 \%$ of the common stock of NYSE- and AMEX-listed corporations are priced at an average premium of $20 \%$ over the post-announcement exchange price. ${ }^{5}$ They conclude that these premiums reflect private benefits that accrue exclusively to the blockholder. Such private benefits would appear to arise only when the blockholder is active in firm management and include (for example) synergies in production for a corporate blockholder and an individual blockholder's large salary as a director or officer.

The pattern of activity we document is also consistent with the finding of Holderness and Sheehan (1985) that six controversial investors who are often portrayed in the financial press as corporate "raiders" are usually active in corporate management after filing an initial 13d. It is further confirmed by the finding of Holderness and Sheehan (1988) that owners of majority blocks of stock in public corporations or representatives of corporations owning such blocks tend to be both directors and officers. In short, there is mounting evidence that large-block shareholders are active investors.

\subsection{Management and board turnover following block trades}

To investigate whether the composition of the top managerial team changes following a block trade, we track turnover among the top three officers and ascertain (to the extent possible) whether the new officers are promoted internally or hired externally. Table 4 reports these data and data on board of director tumover for the four years following a block trade.

(Table 4 goes here)

Previous research on management turnover has focused on the chief executive officer. The CEO turnover following block trades significantly exceeds what is normal for

\footnotetext{
${ }^{5}$ This sample of 63 trades is substantially the same as the 65 firms in the present study that remain independent following a block trade.
} 


\section{Table 4}

Turnover among the top three corporate officers and the board of directors following 65 negotiated block trades of at least $5 \%$ of the common stock of NYSE- or AMEX-listed corporations between 1978 and 1982. All firms remain independent public entities for at least one year following the initial announcement of the block trade. Data from Standard and Poor's Register of Corporations, Directors and Executives.

Year in Relation to Block Trade Announcement

\begin{tabular}{llllll}
\hline 1 & 2 & 3 & 4 & First & First \\
& 2 Years & 3 Years
\end{tabular}

Top officers

CEO turnover (\%)

Percent outsiders

\#2 turnover (\%)

Percent outsiders

\#3 turnover (\%)

Percent outsiders
45

30

43

35

43

35

37

chairmen $(\%)$

Average number

of arriving

board members

Average number

of departing

board members

5

19

64

14

43

25

40

36

50

18

38

34

55

43

30

31

0

29

66

70

8

72

77

77

83

\section{Board of directors}


public corporations. Comment (1985) studies 2731 NYSE- or AMEX-listed corporations between 1975 and 1980 and finds that approximately 5\% of the chief executives turn over annually. Similarly, Warner, Watts, and Wruck (1988), who focus on larger firms, which generally have higher turnover than smaller firms, report annual top management turnover of $18 \%$. In contrast, we find that $45 \%$ of the chief executives (in firms that remain public) depart in the year following a block trade; $19 \%$ more depart in the subsequent year. In full sample, only $22 \%$ of the chief executives at the time of a trade are still chief executives of public corporations three years later. ${ }^{6}$

The turnover among our chief executive officers is similar to the chief executive turnover following more conventional control transactions. For example, Martin and McConnell (1989) find chief executive turnover of $38 \%$ in the first year following a successful tender offer and 19\% in the next year. DeAngelo and DeAngelo (forthcoming) find that in 20 of 39 firms (51\%) where dissidents fail to win a majority of the board seats in proxy contests, the chief executive, president, or chairman resigns within three years. Comment (1985) confirms such turnover following both successful and unsuccessful proxy contests and finds higher-than-normal annual turnover among chief executives following successful mergers (38\%) and successful tender offers [46\%, which is similar to what Martin and McConnell (1989) find].

Table 4 reports that 30\% of the chief executives hired in the first year after a trade and $64 \%$ of those hired in the following year are brought in from the outside. This is abnormally high for public corporations in general but similar to what ensues following other corporate control transactions. Warner, Watts, and Wruck (1988) find that only $19 \%$ of new chief executives are hired externally. Likewise, Reinganum (1985) finds external hires in $13 \%$ of 158 top management changes. In contrast to these studies but similar to what we document with block trades, Martin and McConnell (1989) find that $57 \%$ of the chief executives hired in the first year following a successful tender offer and $54 \%$ of those hired in the succeeding year are outsiders.

${ }^{6}$ Others may remain chief executives after their corporations have been taken private, but we have no way to track managerial tumover after a company ceases to be publicly traded. 
We also document extensive turnover following block trades for subordinate members of the top management team (as classified by Standard and Poor's Register) and for directors. For example, table 4 reports that $43 \%$ of the number two and number three executives leave in the year following a block trade. Although the turnover among these executives drops somewhat in the succeeding years, it nevertheless exceeds the extensive turnover among the chief executives. Turnover among chairmen of the board is almost as pronounced, as 37\% leave in the year following a trade, and within three years there is turnover at $68 \%$ of the firms that remain public. Turnover among directors in general seems to be abnormally high only in the first year after a trade. ${ }^{7}$

Further analysis of the managerial turnover data shows that changes in the top managerial team do not vary with whether the block trading partners are individuals or corporations, with a few exceptions which should be viewed with caution given our small samples. Tumover among chief executives but not among other executives or board members is higher with individual block purchasers ( $81 \%$ turnover) than with corporate purchasers (70\% turnover). This appears to reflect individual purchasers assuming the office of the chief executive. Managerial turnover also tends to be quicker with individual block purchasers.

Combinations of executive turnover offer additional insights into the relation between managerial teams and the arrival of a new blockholder. Only 6 of 66 firms (9\%) experience no turnover among their top three executives in the two years following a trade. On the other hand, 26 firms (40\%) experience turnover in all three positions. But this total turnover seldom occurs within one year, and it seldom involves the wholesale introduction of outsiders. Indeed, in only 3 cases (5\%) does it appear possible that all three new members of the top managerial team are outsiders. Thus, although block trades typically lead to significant turnover among members of the top management team, seldom do we observe the complete replacement of one team with another. A likely reason is that current executives have valuable firm specific information or skills that can not be easily duplicated in a short period. In addition, before replacing top management,

${ }^{7}$ Hermalin and Weisbach (forthcoming) report that for a sample of 142 NYSE corporations director turnover averages approximately one per year per firm. 
a new blockholder may require additional information to identify which executives warrant replacing.

\subsection{Negotiated block trades: Corporate control with a difference}

The evidence in this section identifies negotiated trades of large-percentage blocks as corporate control transactions, even when the firm remains an independent public entity following the trade. The event-study results, combined with the evidence on managerial and board turnover, suggest that most of our large blocks convey sufficient votes for the block purchaser to influence, if not to determine, the composition of the top management team. Such power is seen in the literature as the essence of corporate control. Jensen and Ruback (1983, p. 5), for example, define corporate control as "the rights to hire, fire, and set the compensation of top-level managers."

Placing negotiated block trades in the context of control transactions in diffusely held firms yields several interesting comparisons. For example, table 5 indicates that block trades occur more frequently than either proxy contests or hostile tender offers (both of which, in contrast to block trades, have been extensively analyzed in the academic literature). The abnormal returns associated with block trades that lead to tender offers for the remaining shares are similar in magnitude to the returns for similar transactions in more diffusely held firms, in spite of predictions to the contrary. 8 The abnormal returns associated with block trades in which the firm continues as an independent public entity appear to be approximately the same as the returns associated with proxy contests.

\section{(Table 5 goes here)}

Although block trades are corporate control transactions, they are fundamentally different from the control transactions that have been the focus of most previous research efforts. Jensen and Ruback (1983, p. 6) distinguish between control transactions in which relatively passive shareholders choose among offers for control of the corporation by competing managerial teams and control transactions in which "activist stockholders are

${ }^{8}$ Shleifer and Vishny (1986) predict that takeover premiums will decline in the presence of a large-block shareholder. 


\section{Table 5}

Abnormal stock returns associated with and the frequency per year of various corporate control transactions for NYSE- and AMEX-listed corporations.

$\begin{array}{cc}\text { Abnormal } & \text { Frequency } \\ \text { Stock Return } & \text { per Year }\end{array}$

Negotiated block trades ${ }^{a}$

All trades

Firm remains independent public entity

Firm acquired

within one year

$30 \%$

8

Mergers

$20 \%$ b

$20^{c}$

Tender offers

All tender offers

$30 \%$ b

$33^{\mathrm{d}}$

Hostile tender offers

$35 \%{ }^{e}$

$10^{d}$

Friendly tender offers

$28 \%^{\mathrm{f}}$

$23^{d}$

Going-private transactions

$25 \% 8$

$9^{g}$

Proxy contests

$5 \%$ h

$5^{\text {h }}$

\section{a Table 2.}

bJensen and Ruback (1983), Jarrell, Brickley, and Netter (1988).

'Dodd (1986).

${ }^{d}$ W.T. Grimm \& Co. (1987).

e Dann and DeAngelo (1988).

fJensen and Ruback (1983), DeAngelo, DeAngelo, and Rice (1984), W.T. Grimm \& Co. (1987).

gDeAngelo, DeAngelo, and Rice (1984), Lehn and Poulsen (1987).

${ }^{h}$ Jensen and Ruback (1983), DeAngelo and DeAngelo (forthcoming). 
Page 12

the parties who (alone or in coalition with others) buy control of a company and hire and fire management to achieve a better resource utilization." They point out that many control transactions-mergers, tender offers, going-private transactions, and proxy contests-are best viewed within the paradigm of competing managerial teams. This presumably follows from the diffuse ownership of most public corporations. Negotiated block trades, in contrast, are best viewed within the paradigm of the active investor.

The issue is not the accuracy of the respective paradigms, but which paradigm is appropriate for a given control transaction. The appropriate choice will clarify our understanding not only of the results of a corporate control transaction, but the means used to achieve those results. We now turn to that issue as we seek to understand the sources of value created by active investors in block trades.

\section{Sources of value created by negotiated block trades}

Although it is beyond the scope of this paper to investigate all potential sources of value created by negotiated block trades, we conduct investigations in several areas. We first examine the entire sample to determine whether block trades lead to improved management. We then turn to the firms that remain independent to investigate the impact on firm value of managerial resistance to blockholders and to test the hypothesis that changing managers after a block trade is a major source of value. Finally, we examine the gains that induce some block purchasers eventually to acquire the remaining outstanding shares. In these investigations, we seek not only to understand the value created by block trades but also to gain insight into the broader market for corporate control.

\subsection{Improved management}

We start by inquiring whether large-block trades lead to improved management, in the sense of correcting value-decreasing management decisions or stopping others from being implemented. If this is a major source of value, we expect to observe poor firm performance prior to a trade because such firms offer the greatest opportunities for improvements. We use two measures of a firm's performance in the three years before a block trade (day -760 through day -40). First, we compare our firms' stock returns against the equally weighted returns of all NYSE and AMEX firms. Second, we compare 
our firms' stock returns against the returns of other firms within the same two-digit SIC industry classification to check the robustness of our results and to ascertain the importance of industry-specific effects.

In the three years before a block trade, our sample firms have cumulative abnormal stock returns of $-41.5 \%$ ( $p$-value $=.001$ ) when measured against the market, and $-8.4 \%$ ( $p$-value $=.180)$ when measured against the other firms in their industry. A similar patterns emerges when we partition our sample into those firms that continue as independent public entities following a trade and those that are acquired within one year. The "continuation" sample has pretrade market-adjusted returns of $-44.1 \%$ ( $p$-value = .001 ) and industry-adjusted returns of $-7.6 \%$ ( $p$-value $=.347)$; the "acquired" sample has pretrade market-adjusted returns of $-37.5 \%(p$-value $=.001)$ and industry-adjusted returns of $-9.6 \%$ ( $p$-value $=.332$ ). Thus, firms that are the subject of negotiated block trades, whether they remain independent or are acquired, tend to be marginal performers in poorly performing industries. ${ }^{9}$

If improved management is a significant source of value created by negotiated block trades, we further predict that stock-price increases at the announcement of a trade will be larger, ceteris paribus, when the firm was performing poorly before the trade. Again, this is premised on the assumption that poorly performing firms offer the greatest opportunities for improving management. In table 6 we analyze the relation between pretrade performance and announcement-period returns. We report both the regressions of a firm's announcement-period abnormal return on its pretrade abnormal return (with a dummy variable to distinguish firms acquired within one year of the trade), and to help control for other variables that might affect announcement-period returns, we also include as independent variables (in addition to the takeover dummy) firm size and percentage of the firm's common stock in the block. We alternatively use as the dependent variable the abnormal stock retuins from day -40 through day 40 and those from day -40 through

${ }^{9}$ Mørck, Shleifer, and Vishny (1988) find that when a Fortune 500 firm is performing poorly against the market but not against its industry, the probability of a hostile takeover increases. Martin and McConnell (1989) find that prior to successful tender offers target firms outperform the market but underperform their industry. It thus appears that industry effects arise in corporate control activities in both diffusely held and large-blockshareholder firms. 
day 240 . Retums from day -40 through day 40 have less noise than do the retums from the longer event window. Retums from the longer event window, on the other hand, incorporate more of the changes that follow the trades, including the resolution of attempted takeovers and management tumover. ${ }^{10}$

(Table 6 goes here)

The basic picture that emerges from table 6 for the sample as a whole and for those firms that remain independent is that the worse a firm performs in relation to the market before a block trade, the greater is its stock price increase in relation to the market when a block trade is announced. ${ }^{11}$ These results combined with the poor pretrade performance of our firms suggest that a significant source of value created by negotiated block trades for those firms that continue as independent public entities is improved management (in addition to other benefits from the trade such as synergies in production with a corporate block purchaser). Further, the corporate activities of block purchasers (table 3) suggest that they play a direct role in this management improvement. When the block purchaser acquires the remaining publicly held shares, although management improvements may well take place, other considerations appear to dominate.

${ }^{10}$ The abnormal announcement period stock retums used as independent variables in these regressions are calculated by subtracting the CRSP equally-weighted index return from our sample firms' stock returns. This simple market adjustment is used instead of the market-model prediction errors presented earlier to avoid spurious correlation induced by the fact the market-model coefficients are estimated over part of the same period in which we measure pre-trade performance (the independent variable). Using the marketmodel prediction errors for the analysis in table 6 does not change the qualitative nature of the results, but it does make the results appear much stronger than those we report.

${ }^{11}$ Evaluation of pretrade performance over either one or two years prior to a trade yields qualitively similar findings to the analyses based on a three-year comparison. Evaluation of pretrade performance using industry-adjusted stock returns yields similar, although less significant, results. The same relation persists when we divide our sample into portfolios based on pretrade performance. Firms with stock returns that underperform the market in the three years prior to a trade have average abnormal returns of $18.5 \%$ over the 80 days surrounding the announcement of a block trade. In contrast, those firms that do at least as well the market prior to a trade have announcement returns of only $9.7 \%$ ( $p$-value on the difference in means of these two portfolios is .121). 


\section{Table 6}

Coefficients of ordinary least squares regressions of the market-adjusted abnormal returns over various announcement periods on the performance of the firm in the three years prior to the block trade announcement. The entire sample consists of 106 initial public announcements of negotiated block trades of at least 5\% of the common stock of NYSE- or AMEX-listed corporations between 1978 and 1982. The sample of firms remaining independent public entities consists of 65 trades in which the firms whose shares are traded are not acquired within one year of the block trade announcement. The sample of firms subsequently acquired consists of 41 trades in which the firms whose shares are traded are acquired within one year of the block trade announcement. (p-values in parentheses)

\section{Sample /}

Announcement Period ${ }^{\mathrm{a}}$ Intercept

Entire Sample

-40 to +40

$\begin{array}{ll}.03 & -.09 \\ (.442) & (.037)\end{array}$

-40 to +240

.01

(.879)

-40 to +40

-40 to +240

$\begin{array}{ll}-.08 & -.08 \\ (.407) & (.058)\end{array}$

$-.01$

$(.944)$
Pre-Trade Abnormal

Return

$-.12$

(.046)

$-.11$

$(.073)$
Percent of Equity Purchased

\section{Log of}

Book Value Takeover

of Assets

Dummy
Adjusted $\mathrm{R}^{2}$

Firms Remaining

Independent Public Entities

$\begin{array}{lllll}-40 \text { to }+40 & .02 & -.11 & & \\ & (.472) & (.027) & & \\ -40 \text { to }+240 & -.02 & -.18 & & \\ & (.762) & (.030) & & -.02 \\ -40 \text { to }+40 & .09 & -.10 & .11 & (.355) \\ & (.436) & (.054) & (.636) & -.05 \\ -40 \text { to }+240 & .22 & -.18 & .04 & (.124)\end{array}$

.06

.06

Firms Subsequently

Acquired

$\begin{array}{lllll}-40 \text { to }+40 & .30 & -.07 & & \\ & (.001) & (.456) & & \\ -40 \text { to }+240 & .38 & .01 & & \\ & (.001) & (.863) & & .03 \\ -40 \text { to }+40 & -.15 & -.14 & (.002) & (.404) \\ & (.439) & (.140) & -.002) \\ -40 \text { to }+240 & -.08 & -.05 & .42 & .06 \\ & (.604) & (.527) & (.035) & (.038)\end{array}$

.01

.01

.22

${ }^{a}$ The announcement period is defined in relation to the date of the initial Wall Street Journal announcement of the block trade, day 0 . 
A comparison between the pretrade performance of our firms and the performance of target firms prior to more conventional control transactions suggests that there typically is as much-if not more-opportunity to improve management after a block trade. As reported above, in the three years before a block trade our firms underperform both the market $(-41 \%)$ and the other firms in their industry $(-8 \%)$. In contrast, before more conventional control transactions, target firms have returns which are slightly negative, although a few studies document slightly positive returns. ${ }^{12}$ For example, in a representative study, Kummer and Hoffmeister (1978) examine 50 NYSE firms subject to successful cash tender offers between January 1956 and June 1974 and find (statistically insignificant) cumulative abnormal returns of $-5.3 \%$ from month -40 through month -3 (where month 0 is the month the tender offer is initially announced). Martin and McConnell (1989) find that target firms in 253 successful tender offers between 1958 and 1984 have cumulative abnormal returns from months -45 through month -3 of $8.85 \%$ ( $p$ value $=.045$ )

Few studies have analyzed the relation between pretrade performance and announcement-period retums, as we do in table 6 . In one such analysis, however, Walkling and Edmister (1985) find that the average bid premium in 108 tender offers increases as the firm's market-value-to-book-value ratio decreases. Although this is not the same test we conduct, as with our result, it suggests that the worse a firm performs before a transaction, the greater are the gains to shareholders from the control transaction. It will take future investigations to determine whether the degree of management improvement increases or decreases with active block investors in comparison to the improvements that transpire when diffuse shareholders choose among competing managerial teams.

3.2 Managerial resistance to efforts by block purchasers to influence firm management

To investigate whether the considerable managerial resistance to efforts by blockholders to influence firm management (table 3 ) reflects top management's efforts to entrench themselves or protect minority shareholders, we compare those firms in which management resists the blockholder with those firms where it does not (at least publicly). Because litigation is almost perfunctory with tender offers, we limit our analysis to firms

${ }^{12}$ Gilson (1986, p. 378) summarizes the central findings of nine such studies. 
with no tender offers in the two years following a block trade. The 18 firms in which there is managerial resistance have average abnommal returns of $-2.3 \%$ ( $p$-value $=.95$ ) from day -40 through day 40 and average abnormal returns of $-3.2 \%$ ( $p$-value $=.96$ ) from day -40 through day 240 . In contrast, the 28 firms for which there are no reports of managerial resistance have average abnormal returns of $7.8 \%(p$-value $=.038$ ) from day -40 through day 40 and $13.4 \%(p$-value $=.085)$ from day -40 through day $240 . .^{13}$ It therefore appears that managerial resistance to block purchasers tends to reduce stock prices. Dann and DeAngelo (1988) find that managerial resistance to transfers of control in more diffusely held firms likewise reduces shareholders' wealth. In short, it appears that managers often resist efforts by others-be they active investors or competing managerial teams-to influence firm management.

Events at Treadway Corporation following one of our block trades illustrate the efforts by block purchasers to influence firm management and the lengths which management at times goes to resist them. In November 1978 Care Corporation purchased a block which, together with stock previously acquired, gave it a $24 \%$ interest in Treadway. Initially, Care claimed the block "was for investment purposes only. We're both in the bowling business. We like [Treadway]."14 Several months later, however, Treadway announced that it had retained a New York City law firm "to protect the interests of our stockholders to the fullest" in connection with the block purchase by Care. ${ }^{15}$ Two weeks later Treadway filed suit against Care alleging a "conspiracy to seize control of the corporation [Treadway]."16 The judge in the case issued, but shortly thereafter lifted, a temporary restraining order blocking Care (and its directors and officers) from acquiring additional stock in Treadway. For the following year there was extensive maneuvering by both sides over a slate of directors Care wanted to offer in a

${ }^{13}$ The average percentage of the firm's common stock in the block and the firm's average pretrade performance is similar for the managerial-resistance sample and the noresistance sample.

${ }^{14}$ Wall Street Journal, November 14, 1978, p. 3.

${ }^{15}$ Wall Street Journal, September 13, 1979, p. 4.

${ }^{16}$ Wall Street Journal, September 26, 1979, p. 21. 
proxy contest. Among the steps taken by Treadway's management to resist Care was a private placement of a large block of stock with a friendly company. Care narrowly lost the proxy contest, although initially a federal court awarded it the victory by invalidating the votes cast from the private placement. Finally, two years after the block trade, Treadway repurchased Care's block at a $38 \%$ premium to the exchange price.

\subsection{Changing managers as a source of value}

We now test the hypothesis that the management improvements suggested by our cross sectional analysis (table 6) consist of replacing top managers after a trade. If this is the case, the worse a firm's pretrade performance, the more likely it should be that the block purchaser replaces members of the top managerial team. Accordingly, we compare the pre and post trade performance for those firms that replace their chief executive officer (or at least two of the top three managers) in the two years following a trade and those firms that do not. We also conduct a logit analysis with chief executive turnover (or turnover of at least two of the top three managers) in the two years following a trade as the dependent variable and pretrade performance, firm size, and fractional size of the block as the independent variables. We examine only those firms that remain public for at least one year following a block trade, as we have data on managerial turnover only when firms are public. Results of these tests are reported in table 7.

\section{(Table 7 goes here)}

Before turning to the relation between pretrade performance and post-trade managerial tumover, we note that the coefficients for the percentage of the firm's stock in the block trade (bottom panel in table 7) in all four regressions are positive and significant. This suggests that the greater the percentage of the firm's common stock in the block, the greater is the block purchaser's power to replace management. Nevertheless, the data in table 7 do not support the hypothesized inverse relation between firm performance before a trade and managerial turnover afterward. For example, the pretrade performance in relation to their industry of the firms that retain their chief executives in the two years following a trade is actually worse than the pretrade performance of those that replace their chief executives. In the regressions, the probability of post-trade chief 


\section{Table 7}

Analysis of the relation between firm performance in the three years prior to 65 negotiated block trades of at least $5 \%$ of the common stock of NYSE- or AMEX-listed corporations and turnover among various combinations of top managers of the firm in the two years following the block trade. All firms remain independent public entities for at least one year following the announcement of the block trade. The top panel compares the prior performance of those firms that replace various combinations of top managers after a trade with the prior performance of those firms not replacing their managers. The bottom panel reports logit regression coefficients where the dependent variable is post-trade managerial turnover and the independent variables are the performance of the firm in the three years prior to the trade, the percentage of the firm's common stock in the block trade, and the log of the book value of the firm's assets. Prior firm performance in both panels is measured over the three years before a trade (days -760 through -40 , where day 0 is the initial Wall Street Journal announcement of the trade) and is evaluated alternatively against the stock returns of all other firms with the same two-digit SIC code and against the stock returns of all NYSE- and AMEX-listed firms. Management turnover from Standard and Poor's Register of Corporations, Directors and Executives. ( $p$-values in parentheses) (1978-1982)

Panel A

\begin{tabular}{|c|c|c|c|c|c|c|}
\hline & \multicolumn{3}{|c|}{$\begin{array}{l}\text { CEO Turnover within } 2 \text { Years } \\
\text { Following a Block Trade }\end{array}$} & \multicolumn{3}{|c|}{$\begin{array}{l}\text { Turnover of at Least } 2 \text { of } 3 \\
\text { Top Officers within } 2 \text { Years } \\
\text { Following a Block Trade }\end{array}$} \\
\hline & Yes & No & $\begin{array}{l}p \text {-value on } \\
\text { difference }\end{array}$ & Yes & No & $\begin{array}{l}p \text {-value on } \\
\text { difference }\end{array}$ \\
\hline Number of observations & 29 & 35 & & 42 & 22 & \\
\hline $\begin{array}{l}\text { Pre-trade performance } \\
\text { relative to industry }\end{array}$ & 3.22 & -16.57 & .238 & -12.26 & .78 & .407 \\
\hline $\begin{array}{l}\text { Pre-trade performance } \\
\text { relative to market }\end{array}$ & .49 .05 & -39.99 & .582 & .51 .66 & -30.29 & .197 \\
\hline $\begin{array}{l}\text { Abnormal return } \\
\text { event day }-40 \text { to }+40\end{array}$ & 3.94 & 7.19 & .246 & 3.96 & 9.06 & .484 \\
\hline $\begin{array}{l}\text { Abnormal return } \\
\text { event day }-40 \text { to }+240\end{array}$ & 5.89 & 5.40 & .516 & 3.88 & 8.94 & .849 \\
\hline
\end{tabular}

Panel B

\begin{tabular}{|c|c|c|c|c|c|}
\hline $\begin{array}{l}\text { Dependant } \\
\text { Variable }\end{array}$ & Intercept & $\begin{array}{l}\text { Return } \\
\text { Relative } \\
\text { to Industry }\end{array}$ & $\begin{array}{l}\text { Return } \\
\text { Relative } \\
\text { to Market }\end{array}$ & $\begin{array}{l}\text { Percent } \\
\text { of Equity } \\
\text { Purchased }\end{array}$ & $\begin{array}{l}\text { Log of } \\
\text { Book Value } \\
\text { of Assets }\end{array}$ \\
\hline $\begin{array}{l}\text { CEO turnover } \\
\text { within } 2 \text { years }\end{array}$ & $\begin{array}{l}-.90 \\
(.398)\end{array}$ & $\begin{array}{l}0.88 \\
(.079)\end{array}$ & & $\begin{array}{l}6.36 \\
(.015)\end{array}$ & $\begin{array}{l}-.14 \\
(.467)\end{array}$ \\
\hline $\begin{array}{l}\text { CEO tumover } \\
\text { within } 2 \text { years }\end{array}$ & $\begin{array}{l}-.38 \\
(.701)\end{array}$ & & $\begin{array}{l}.05 \\
(.909)\end{array}$ & $\begin{array}{l}4.86 \\
(.039)\end{array}$ & $\begin{array}{l}.19 \\
(.287)\end{array}$ \\
\hline $\begin{array}{l}\text { Turnover of at least } \\
2 \text { of } 3 \text { top officers }\end{array}$ & $\begin{array}{l}.37 \\
(.737)\end{array}$ & $\begin{array}{l}. .21 \\
(.656)\end{array}$ & & $\begin{array}{l}4.43 \\
(.091)\end{array}$ & $\begin{array}{l}. .15 \\
(.425)\end{array}$ \\
\hline $\begin{array}{l}\text { Turnover of at least } \\
2 \text { of } 3 \text { top officers }\end{array}$ & $\begin{array}{l}.22 \\
(.843)\end{array}$ & & $\begin{array}{l}-.38 \\
(.431)\end{array}$ & $\begin{array}{l}4.22 \\
(.107)\end{array}$ & $\begin{array}{l}. .14 \\
(.462)\end{array}$ \\
\hline
\end{tabular}


executive tumover decreases with poor pretrade performance in relation to the industry, and here the relation is significant ( $p$-value $=.079$ ).

If post trade managerial tumover is a major source of gain in block trades, we also predict a positive relation between post announcement stock retums and managerial rumover. We do not find such a relation. Firms retaining their chief executives for at least two years after a trade have abnormal returns of $7.2 \%$ from days -40 to day 40 and $5.4 \%$ from days -40 to day 240 . Firms replacing their chief executives have returns of $3.9 \%$ and $5.8 \%$ over the respective event periods. ${ }^{17}$

Our findings on firm performance before a trade and managerial turnover after a trade contrast with those of Martin and McConnell's (1989) for 253 successful tender offers between 1958 and 1984. They report that firms with chief executive turnover following consummated tender offers tend to have performed poorly compared with their industry and about as well as the market. Firms retaining their chief executives, on the other hand, tend to perform significantly better than the market and about as well as their industry in the pretrade period. The pretrade performance of their no-tumover sample, in relation both to the market and the industry, is significantly better that the pretrade performance of the firms that replace their chief executives. This is the opposite of what we find.

Several explanations are possible for why our data do not support the hypothesis that post trade managerial turnover is a source of gain in negotiated block trades. The extent of the post trade tumover (table 4), the problems with using stock returns to measure managerial effectiveness, and the fact that some of our turnover represents the retirement of individual block sellers who were viewed as effective executives, all present practical problems with identifying any disciplinary management turnover that may be occurring.

The top managerial team is also likely to assume a different role when a blockholder is active in management. For example, a change in blockholders can substitute for a change in managers. This would be the case if blockholders employ managers not in their usual role to initiate major corporate decisions but only to implement them.

${ }^{17}$ Differences between both samples are insignificant. 
Moreover, it is not necessary to change top managers to improve management, particularly when a blockholder is involved in management and can thus direct and monitor other executives. This explanation is consistent with the difference between our evidence and that of Martin and McConnell. In any event, the role of top managers when a blockholder is active in firm management is a topic which warrants future investigation.

3.4 Value created by changing the organizational form

Finally, we tum to the gains that induce some of our purchasers to acquire not only a large-percentage block but the remaining outstanding shares as well. Why not, as with $60 \%$ of our purchasers, simply manage or monitor the firm using the decision rights that come with large-block ownership? Cross sectional analysis of the announcement period abnomal stock returns (table 6) indicates that something beyond the mere expectation of improved management is occurring when a block purchaser decides to acquire the remaining shares. We start our investigation of this issue by conducting a logit regression with a blockholder's acquisition of the minority's interest within five years of the trade as the dependent variable and (as in previous logits and regressions) firm size, fraction of the firm's common stock in the block, and prior firm performance in relation to the other firms in the same industry as the independent variables (with $p$-values in parentheses):

$$
\begin{aligned}
\text { Probability of takeover }=F( & -2.95+.25 \text { Assets }+5.93 \text { Fraction of stock in block } \\
& (.002)(.127) \quad(.001) \\
& +.34 \text { Prior firm performance })
\end{aligned}
$$

Number of firms $=96$.

This logit reveals that the probability of a block purchaser's acquisition of the remaining shares increases, ceteris paribus, with the fraction of the firm's cummon stock in the block trade. ${ }^{18}$ On first impression, we find this perplexing because increased fractional ownership should give a blockholder more decision rights over management and thus greater power to improve management. We previously reported that when a firm

${ }^{18}$ Logit analysis using as the dependent variable a blockholder's acquisition of the remaining shares within one year of the trade (instead of five years) yields similar results. 
remains public following a block trade, the probability of management turnover increases significantly with the fractional size of the block. Indeed, block purchasers often become top managers and directors themselves. These findings suggest that block purchasers do not acquire the interest of minority shareholders primarily to change the top management team-as they apparently can do this by merely acquiring a block.

Instead, it appears that blockholders value the additional decision rights they obtain when they acquire the minority's interest and in so doing fundamentally change the organizational form in one of two ways. First, there is the change from public to private ownership that occurs when an individual, group of individuals, or private corporation owning a large-percentage block acquires the remaining publicly held shares. Second, there is the elimination of overlapping public claims to the same residual cash flows that occurs when a public corporation acquires the remaining publicly held shares in what is effectively a partially owned subsidiary. Because going-private transactions and the gains they generate have been investigated by others, we focus on the decision of corporate block purchasers to acquire all of the shares in a partially owned subsidiary. ${ }^{19}$

Although it is beyond the scope of this paper to analyze fully the particular gains created when corporate blockholders acquire the remaining publicly held shares in a partially owned subsidiary, we can investigate whether shareholders of the combined enterprise are made better off by the decision. Target firm shareholders are on average certainly made better off, as figure 1 and table 2 show that abnormal stock-price increases are approximately five times greater when a blockholder acquires their interest within one year of the trade. When we examine only the trades where a corporate blockholder acquires the minority's interest within five years, the same pattern holds: abnormal returns are approximately 4.5 times larger (31.7\% versus $7.0 \%$ ).

This evidence notwithstanding, given the broad management rights vested in blockholders it is not unreasonable to ask whether it is a "mistake" for corporate

${ }^{19} \mathrm{Among}$ the benefits of going private are: tax savings, eliminating the direct costs of SEC filing, and avoiding the competitive and political costs that can be a by-product of SEC disclosure requirements. See DeAngelo, DeAngelo, and Rice (1984), and Kaplan (1988). 
blockholders to incur the considerable expense to acquire the minority's interest. ${ }^{20}$ Indeed, as successful a block investor as Warren Buffet explicitly advises acquiring only a large-percentage block and not an entire firm for this very reason. ${ }^{21}$ In other words, the abnormal returns for target firm shareholders could simply reflect transfers from the shareholders of the corporate blockholder to shareholders of the target firm. This does not appear to be the case, however, as the market-model adjusted returns for the 28 corporate blockholders (which have stock returns on the CRSP NYSE, AMEX, or NASDAQ computer tapes) average $0.8 \%$ when they announce their acquisition of the minority's interest (days $-1,0) .^{22}$ This finding, which is similar to the returns to bidding firms in more conventional control transactions, offers no evidence that it is a "mistake" for a corporate blockholder to acquire the minority's interest.

The particular benefits created when a corporate blockholder buys out the minority in a partially owned, publicly traded subsidiary are likely to vary with the transaction. Casual reading of the financial press, however, identifies a number of lawsuits brought by minority shareholders against a corporate blockholder alleging usurpation of business opportunities that were first offered to the firm and could have been profitably undertaken by it. There are other reports of minority shareholders challenging transfer pricing schemes between the firm and its corporate blockholder. Such anecdotal evidence suggests that there are gains from eliminating potential conflicts-of-interest that can arise when two groups of public shareholders have potential claims to the same cash flows. It seems reasonable to hypothesize that these conflicts are more likely to arise when firms are in the same or related lines of businesses. ${ }^{23}$ To this end, we note that 15 of our 22

\footnotetext{
${ }^{20}$ Such "mistakes" may reflect agency problems in the acquiring firms. See Roll (1986).

${ }^{21}$ Wall Street Journal, June 25, 1987, p. 22.

${ }^{22}$ This return, which is not significantly different from zero, is calculated with the same event study methodology described previously.

${ }^{23}$ Such conflicts-of-interests and the minority litigation it can trigger was a primary reason cited by British Petroleum for their decision to spend $\$ 585$ million to acquire the $45 \%$ of the shares of Standard Oil of Ohio which it did not own. N.Y. Times, January 18, 1988.
} 
Page 22

acquisitions (68\%) involve firms in related business. Whether the elimination of such conflicts-of-interest is indeed a source of value when corporate block purchasers acquire the minority's interest, however, remains to be investigated.

\section{Conclusion}

This paper analyzes 106 negotiated block trades involving at least 5\% of the common stock of NYSE- and AMEX-listed corporations. We document that these trades are associated with average abnormal stock-price increases of $16.5 \%$; such increases are larger when the block purchaser eventually acquires the minority's interest. But even when a firm continues as an independent public entity, cumulative abnormal stock returns average $5.6 \%$ one year after the trade. The trades are generally followed by activity and change within the corporation. Most strikingly, in those firms that remain public $(60 \%$ of our sample), turnover among top managers is far higher than normal for public corporations: $64 \%$ of the firms replace their chief executives within two years. Turnover among other members of the top managerial team is equally pronounced. We also document numerous cases of block purchaser involvement in firm management-sometimes directly, through service as officers and directors, sometimes indirectly, through negotiations with management. In some firms, management publicly resists efforts by the block purchasers to influence corporate policy, and this appears to reduce firm value.

Our analyses distinguish several sources of value created by negotiated block trades. In general, block trades lead to improved management, as the worse a firm performs before a trade, the greater is the increase in value associated with the trade. Such improvement, however, does not appear to involve replacing top managers. In contrast to control transactions in diffusely held firms, in our sample the worse a firm performs before a trade, the less likely the chief executive is to be replaced after a trade. In light of the extensive involvement of many blockholders in firm management, the possibility is raised that the blockholder is the key manager, and the other members of the top managerial team play a different role than they do in diffusely held firms.

Large gains from block trades-and certainly the largest on average for minority shareholders-appear to come from changing the organizational form from public to private ownership or from eliminating overlapping claims of different sets of public 
shareholders to the same residual cash flows. Both organizational changes occur when a block purchaser acquires the remaining shares (either simultaneous with the trade or later). Recent antitakeover laws and corporate charter amendments dictate that under some circumstances an individual or corporation can accumulate or purchase a largepercentage block of stock but cannot acquire the remaining shares for a specified period (three years under Delaware law). This is analogous to the difference between a block trade in which the firm continues as an independent public entity and a block trade followed by the acquisition of the minority's shares. Our results clearly show that these transactions are not close substitutes, and delaying full acquisition of a firm by a blockholder is likely to reduce the wealth of minority shareholders.

Finally, our findings suggest a threefold modification in the prevailing view of the market for corporate control. First, negotiated trades of large-percentage blocks of common stock are corporate control transactions. Given the frequency of block trades, the extent of concentrated stock ownership in public corporations, and the reports of a resurgence in block investing both in this country and in Europe, this is a significant addition to the accepted list of corporate control transactions. Second, corporate control involves more than the legal rights to hire, fire, and set the compensation of top management. The purchase of a large-percentage block of stock often conveys these rights, yet many block purchasers choose to incur the considerable expense to buy out minority shareholders, and stock-price increases are typically much larger when they do so. This implies that the bundle of managerial rights-possibly what management decisions may be undertaken unfettered by minority shareholder litigation-changes with the organizational form. In other words, corporate control consists not only of who holds the bundle of management rights, but the composition of that bundle as well. Third, our findings point out that for understanding some corporate control transactions-including negotiated block trades-a market in which active large-block investors pursue gains by initiating corporate change is a more useful paradigm than the traditional model of passive investors choosing among competing managerial teams. 


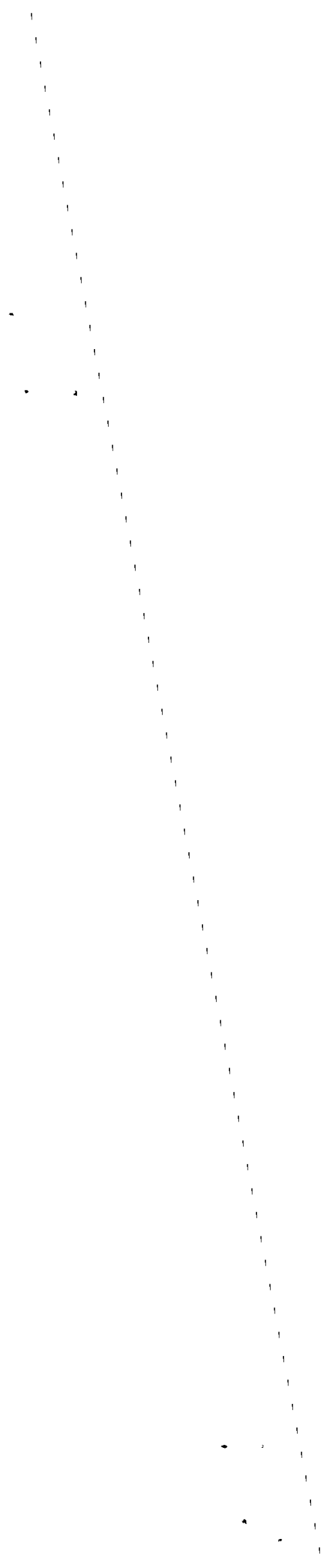




\section{References}

Barclay, Michael J. and Clifford G. Holderness, Private benefits from control of public corporations, Unpublished manuscript (University of Rochester, Rochester, NY).

Comment, Robert, 1985, The effects of firm-specific human capital on management equity investment and turnover, Unpublished manuscript (University of Michigan, Ann Arbor, $\mathrm{Ml}$ ).

Dann, Larry Y. and Harry DeAngelo, 1988, Corporate financial policy and corporate control: A study of defensive adjustments in assets and ownership structure, Journal of Financial Economics 20, 87-127.

DeAngelo, Harry and Linda DeAngelo, forthcoming, The role of proxy contests in the governance of publicly held corporations, Journal of Financial Economics.

DeAngelo, Harry, Linda DeAngelo, and Edward M. Rice, 1984, Going Private: Minority freezeouts and stockholder wealth, Journal of Law and Economics 27, 367-401.

Dodd, Peter, 1986, The market for corporate control: A review of the evidence, in: Joel M. Stern and Donald H. Chew, Jr., ed., The revolution in corporate finance (Basil Blackwell, New York, NY).

Gilson, Ronald J., 1986, The law and finance of corporate acquisitions (Foundation Press, Mineola, NY).

Holderness, Clifford G. and Dennis P. Sheehan, 1985, Raiders or Saviors? The evidence on six controversial investors, Journal of Financial Economics 14, 555-579.

Holderness, Clifford G. and Dennis P. Sheehan, 1988, The role of majority shareholders in publicly held corporations: An exploratory analysis, Joumal of Financial Economics 20, 317-346.

Hermalin, Benjamin and Michael Weisbach, forthcoming, The Determinants of board composition, Rand Journal of Economics.

Jarrell, Greg A., James A. Brickley, and Jeffry M. Netter, 1988, The market for corporate control: The empirical evidence since 1980, Journal of Economic Perspectives 2, 49 . 68.

Jensen, Michael C., 1989, Active investors, LBOs, and the privatization of bankruptcy, Unpublished manuscript (Harvard University, Boston, MA).

Jensen, Michael C. and Richard S. Ruback, 1983, The market for corporate control: The scientific evidence, Journal of Financial Economics 11, 5-50. 
Kaplan, Steven, 1988, Management buyouts: Efficiency gains or value transfers?, Unpublished manuscript (University of Chicago, Chicago, IL).

Kummer, D. and R. Hoffmeister, 1978, Valuation consequences of cash tender offers, Joumal of Finance 33, 505-516.

Lehn, Kenneth and Annette B. Poulsen, 1987, Sources of value in leveraged buyouts, in: Public policy towards corporate takeovers (Transaction Publishers, New Brunswick, $\mathrm{NJ})$.

Martin, Kenneth J. and John J. McConnell, 1989, Corporate performance, corporate takeovers, and management turnover, Unpublished manuscript (Purdue University, West Lafayette, IN).

Mørck, Randall, Andrei Shleifer, and Robert W. Vishny, 1988, Characteristics of targets of hostile and friendly takeovers, in: Alan J, Auerbach, ed., Corporate Takeovers: Causes and Consequences (University of Chicago Press, Chicago, IL).

Reinganum, M.R., 1985, The effect of executive succession on stockholder wealth, Administrative science quarterly $30,46-60$.

Roll, Richard, 1986, The hubris hypothesis of corporate takeovers, Journal of Business 59, 197-216.

Shleifer, Andrei and Robert W. Vishny, 1986, Large shareholders and corporate control, Journal of Political Economy 94, 461-488.

Walkling, Ralph A., and Robert O. Edmister, 1985, Determinants of tender offer premiums, Financial Analysts Journal (January-February 1985) 27-37.

Warner, Jerold B., Ross L. Watts, and Karen H. Wruck, 1988, Stock prices and top management changes, Journal of Financial Economics 20, 461-492.

W.T. Grimm \& Company, 1987, Mergerstat review (W.T. Grimm \& Co., Chicago, IL). 